\title{
Impact of Climate CHANGE on Agriculture and Allied Activities in Jagatsinghpur District of Odisha, India
}

\author{
Debasmita Nayak*, Mita Meher, Sushree Purabi Panigrahi and S.P Sangramsingh \\ Department of Extension Education, College of Agriculture, OUAT, India
}

*Corresponding author

\section{A B S T R A C T}

\begin{tabular}{|l|}
\hline K e y w o r d s \\
Climate, \\
Agriculture, \\
Sowing, Spacing, \\
Land preparation, \\
Straw yield, \\
Irrigation, Disease \\
infestation, \\
Pesticide and insect, \\
Pest infestation \\
\hline Article Info \\
\hline Accepted: \\
15 August 2019 \\
Available Online: \\
10 September 2019 \\
\hline
\end{tabular}

\section{Introduction}

Climate change is one of the biggest environmental issues facing the world today. Climate change refers to any change in climate, whether due to natural variability and/or as a result of human activity $(1,2)$. There are already increasing concern globally regarding climate change that affects the environment and livelihood. Now a days most of the countries are facing the problems of rising temperature, rising sea level, changes in
Agriculture and climate change are inextricable. Crop yield, biodiversity, water use, and soil health are directly affected by the impact of climate change. Tropical countries are likely to be more affected compared to temperate countries. The brunt of environmental changes in India is very high due to higher dependence on agriculture. Such a study would contribute towards a better understanding of the intensity and impacts of the climate change. The research study was conducted in Jagatsinghpur district of Odisha taking 120 respondents from Tirtol and Raghunathpur block. From the study it was observed that $53.33 \%$ of respondents solely depend on agriculture. The study revealed that $58.33 \%, 55.83 \%, 54.16 \%$, $54.16 \%, 53.33 \%$ of the respondents observed negative impact on sowing time, spacing, grain yield quantity, straw yield and land preparation respectively. $44.16 \%, 40.83 \%, 40.83 \%, 39.16 \%$ felt increasing of number of irrigation, Disease infestation, pesticide use, and insect, pest infestation respectively. $49.16 \%$ observed no effect on disease infestation, number of irrigation and pesticide use. 
water, pollination, nutrient cycling, genetic resources and biodiversity. Adaptation strategies should be introduced in response to climate change to reduce negative effects and exploit potential positive ones.

According to the assessment by the EEA, European Commission, OECD, the World Wide Fund for Nature, IUCN, and various UN bodies for Europe, in many regions there is increase in irrigated area and water abstraction for irrigation. In the northern temperate region agro-climatic zones are likely to move northwards as a result of climate change. In the southern areas, current crop areas may be abandoned due to very low availability of water $(5,6,7)$.

The impact of climate change on agriculture is severely felt in India. It has been predicted that under the scenario of a $2.5^{\circ} \mathrm{C}$ to $4.9^{\circ} \mathrm{C}$ temperature will rise, rice yields will drop by $32 \%-40 \%$ and wheat yields by $41 \%-52 \%$. This will cause the GDP to fall by $1.8 \%-3.4 \%$. Understanding on global climate and its change is pre requisite to take appropriate initiatives to combat climate change. The only solution for these huge populations seems to be adequate adaptation strategies.

\section{Materials and Methods}

Research methodology refers to the structural configuration of the study for conducting research within the frame work of the objectives. It includes different types of methods, tools, techniques and approaches for any research work. Moreover, research methodology is concerned with the objective verification which requires logical analysis of problems and devising appropriate procedure to obtain evidence.

A research design is defined as the programme that guides the researcher in the process of collecting, analysing and interpreting observations to draw inferences. The present study comes within the purview of survey research mainly to 'Ex-post facto in nature.

For the present study we had selected two blocks Tirtol and Raghunathpur from the 8 blocks of Jagatsinghpur district by random sampling method. Then we had selected 8 villages ( 4 from each block). In the study we had taken the views of 120 farmers who were selected through disproportionate random sampling method from the 8 villages (15 from each village). We had conducted a pilot study and also pre testing of the interview schedule was done taking $10 \%$ of the total respondents i.e. 12 number of respondents.

Personal interview and focused group discussion techniques were followed for collection of information. Different statistical tools like percentage, frequency were followed.

\section{Results and Discussion}

\section{Socio-economic characteristics of farmers}

The socio-personal characteristics are defined on the basis of personal, social, economic characters. Respondents were categorized and their frequency and percentage was calculated for further analysis. From this study it is observed that most of the respondents i.e. $40 \%$ belong to middle aged category while $38.33 \%$ were old aged and $21.66 \%$ were young.

The findings reveal that the majority of respondents $34.16 \%$ were high school pass out where $7.5 \%, 13.33 \%, 21.66 \%, 23.33 \%$ were illiterate, could read and write, primary school pass out and college pass out respectively.

As regards the family type, it has been observed that most of the respondents $56.66 \%$ belong to the joint family where $43.33 \%$ belong to nuclear family.

From this study it is observed that most of the 
respondents (45.83\%) have 20-40 years of experience while $30 \%$ have upto $20 \%$ experience and $24.16 \%$ have more than $40 \%$ experience.

Further, the land holding of the farmers reveal that that most of the respondents i.e $60 \%$ of the respondents have upto 1 hac of land and
$34.16 \%$ and $5.83 \%$ of the respondents have 1-2 hac land and $>2$ hac land respectively.

The findings about family income reveal that majority of respondents (40\%) have annual income of Rs. 20000-Rs 40000 while 33.33\%, $15 \%$ and $11.66 \%$ have Rs. $40000-60000$, >Rs 60000 and below Rs. 20000 respectively.

Table.1 Distribution of the respondents according to their socio economic characteristics $(n=120)$

\begin{tabular}{|c|c|c|c|}
\hline Characteristics & Category & Frequency & Percentage \\
\hline \multirow[t]{3}{*}{ Age } & Upto 35years & 26 & 21.67 \\
\hline & $36-50$ years & 48 & 40 \\
\hline & $>50$ years & 46 & 38.33 \\
\hline \multirow[t]{5}{*}{ Education } & Illiterate & 9 & 7.5 \\
\hline & Read and write & 16 & 13.33 \\
\hline & Primary school & 26 & 21.67 \\
\hline & High school & 41 & 34.16 \\
\hline & College and above & 28 & 23.34 \\
\hline \multirow[t]{2}{*}{ Family type } & Nuclear & 52 & 43.33 \\
\hline & Joint & 68 & 56.67 \\
\hline \multirow[t]{3}{*}{ Farming experience } & 20 years & 36 & 30 \\
\hline & $20-40$ years & 55 & 45.84 \\
\hline & $>40$ years & 29 & 24.16 \\
\hline \multirow[t]{3}{*}{ Land holding } & Upto 1 hac & 72 & 60 \\
\hline & $1-2$ hac & 41 & 34.16 \\
\hline & $<2$ hac & 7 & 5.84 \\
\hline \multirow[t]{4}{*}{ Annual income } & Upto Rs20000 & 14 & 11.66 \\
\hline & Rs20000-40000 & 48 & 40 \\
\hline & Rs $40000-60000$ & 40 & 33.34 \\
\hline & $>$ Rs 60000 & 18 & 15 \\
\hline
\end{tabular}


Table.2 Distribution of respondents according to their view on impact of climate change on agriculture $(n=120)$

\begin{tabular}{|c|c|c|c|c|c|c|c|}
\hline \multirow[t]{3}{*}{ SI. No. } & \multirow[t]{3}{*}{ Farming practices } & \multicolumn{6}{|c|}{ Effect of climate change } \\
\hline & & \multicolumn{2}{|c|}{ Positive } & \multicolumn{2}{|c|}{ Negative } & \multicolumn{2}{|c|}{ No Effect } \\
\hline & & $\mathbf{F}$ & $\mathbf{P}$ & $\mathbf{F}$ & $\mathbf{P}$ & $\mathbf{F}$ & $\mathbf{P}$ \\
\hline 1 & Soil fertility & 12 & 10 & 64 & 53.33 & 44 & 36.6 \\
\hline 2 & Crops grown & 15 & 12.5 & 45 & 37.5 & 60 & 50 \\
\hline 3 & Cropping pattern & 18 & 1512.5 & 48 & 40 & 54 & 45 \\
\hline 4 & Variety selection & 15 & 12.5 & 45 & 37.5 & 60 & 50 \\
\hline 5 & Land preparation & 12 & 10 & 64 & 53.33 & 44 & 36.6 \\
\hline 6 & Sowing time & 8 & 6.66 & 70 & 58.33 & 42 & 35 \\
\hline 7 & Spacing & 13 & 18.3 & 67 & 55.83 & 40 & 33.33 \\
\hline 8 & Seed treatment & 10 & 8.33 & 12 & 10 & 98 & 81.66 \\
\hline 9 & FYM application & 20 & 16.66 & 22 & 18.33 & 78 & 65 \\
\hline 10 & Use of chemical fertilizers & 39 & 32.5 & 25 & 20.83 & 56 & 46.66 \\
\hline 11 & Time of application & 11 & 9.16 & 10 & 8.33 & 99 & 82.5 \\
\hline 12 & Intercultural operations & 40 & 33.33 & 32 & 26.66 & 48 & 40 \\
\hline 13 & Weed growth & 20 & 16.66 & 58 & 48.33 & 42 & 35 \\
\hline 14 & Insect, pest infestation & 47 & 39.16 & 10 & 8.33 & 63 & 52.5 \\
\hline 15 & Disease infestation & 49 & 40.83 & 12 & 10 & 59 & 49.16 \\
\hline 16 & Pesticide use & 49 & 40.83 & 12 & 10 & 59 & 49.16 \\
\hline 17 & No. of irrigations & 53 & 44.16 & 8 & 6.66 & 59 & 49.16 \\
\hline 18 & Harvesting & 23 & 19.16 & 48 & 40 & 49 & 40.83 \\
\hline 19 & Grain yield quality & 10 & 8.33 & 60 & 50 & 50 & 41.66 \\
\hline 20 & Grain yield quantity & 5 & 4.16 & 65 & 54.16 & 50 & 41.66 \\
\hline 21 & Straw yield & 6 & 5 & 65 & 54.16 & 49 & 40.83 \\
\hline 22 & Storage & 22 & 18.33 & 22 & 18.33 & 76 & 63.33 \\
\hline 23 & Market price & 39 & 32.5 & 31 & 25.83 & 50 & 41.66 \\
\hline 24 & Overall health of the crop & 12 & 10 & 62 & 51.66 & 46 & 38.33 \\
\hline 25 & Shelf life of the crop & 8 & 6.66 & 64 & 53.33 & 48 & 40 \\
\hline 26 & Storage pests and diseases & 50 & 41.66 & 12 & 10 & 58 & 48.33 \\
\hline 27 & Taste of the produce & 7 & 5.83 & 69 & 36.66 & 44 & 36.66 \\
\hline 28 & Any other & 21 & 17.5 & 40 & 33.33 & 59 & 49.16 \\
\hline
\end{tabular}


Table.3 Distribution of respondents according to their view on impact of climate change on allied activities $(n=120)$

\begin{tabular}{|l|l|l|l|l|l|l|l|}
\hline SI no & STATEMENTS & \multicolumn{2}{|l|}{ AGREE } & \multicolumn{2}{|l|}{ DISAGREE } & \multicolumn{2}{|l|}{ CAN'T SAY } \\
\hline $\mathbf{1}$ & $\begin{array}{l}\text { Species of some animal } \\
\text { and bird has extinct }\end{array}$ & 81 & 67.5 & 14 & 11.67 & 25 & 20.83 \\
\hline $\mathbf{2}$ & $\begin{array}{l}\text { Scarcity of fodder in the } \\
\text { area }\end{array}$ & 84 & 70 & 14 & 11.67 & 22 & 18.33 \\
\hline $\mathbf{3}$ & $\begin{array}{l}\text { Behavioural changes and } \\
\text { adverse effect on health of } \\
\text { livestock }\end{array}$ & 69 & 57.5 & 13 & 10.84 & 38 & 31.66 \\
\hline $\mathbf{4}$ & $\begin{array}{l}\text { New fish species found } \\
\text { and old species have } \\
\text { extinct in rivers }\end{array}$ & 66 & 55 & 8 & 6.67 & 46 & 38.33 \\
\hline $\mathbf{5}$ & \begin{tabular}{l} 
Pollutions are increasing \\
\hline
\end{tabular} & 86 & 71.67 & 0 & 0 & 34 & 28.33 \\
\hline
\end{tabular}

\section{Impact of climate change on agriculture}

Climate change impact and associated vulnerabilities are of particular to developing countries where large parts of the population depend on climate sensitive sectors like agriculture for livelihood. Impact of climate change at local level is difficult to assess due to poor understanding of microclimate. Most of the farming communities cannot classify the concept climate change but are good at describing changes in weather and its impact. Farmers were asked about changes occurred in agriculture and allied activities according to their past experiences as impact of climate change.

From the table it was observed that majority of farmers $81.66 \%$ observed no effect on seed treatment, $58.33 \%, \quad 55.83 \%, 54.16 \%$, $54.16 \%, 53.33 \%$ observed negative impact on sowing time, spacing grain yield quantity, straw yield and land preparation respectively. $44.16 \%, 40.83 \%, 40.83 \%, 39.16 \%$ felt increasing of number of irrigation, Disease infestation, pesticide use, and insect, pest infestation respectively. $49.16 \%$ observed no effect on disease infestation, number of irrigation and pesticide use.
From this table it is observed that most of the respondents $71.66 \%$ felt that pollutions are increasing due to climate change. $70 \%$, $67.5 \%, 57.5 \%, 55 \%$ experienced scarcity of fodder, extinction of species, adverse effect on livestock, effect on fishes as the impact of climate change.

In the study area the respondents viewed pollution and scarcity of fodders as most serious impact of climate change.

Summary and conclusion are as follows; Climate change will bring about changes in weather patterns, river systems, crop yields and impact people. Climate is closely related to human and economic activities including agricultural system. Some changes in climate will affect agriculture through their direct and indirect effects on crops, livestock, fisheries etc. Tropical countries are likely to be affected more as compared to the temperate countries. The brunt of environmental changes is expected to be very high in India due to greater dependence on agriculture, alarming increase in human and livestock population, changing pattern in land use and socio-economic factors that create a great threat in meeting the food, fibre, fuel and 
fodder requirement. The findings from the study conclude that there was both positive and negative impact of climate. $58.33 \%$, $55.83 \%, 54.16 \%, 54.16 \%, 53.33 \%$ observed negative impact on sowing time, spacing grain yield quantity, straw yield and land preparation respectively where $18.44 .16 \%$, $40.83 \%, 40.83 \%, 39.16 \%$ felt increasing of number of irrigation, disease infestation, pesticide use, and insect, pest infestation respectively. In the study area most of the respondents $71.66 \%$ felt that pollutions are increasing due to climate change.

\section{References}

1. Akerman EK. 2010. Farmers' perception of climate change and adaptation strategies in Sub-Saharan West-Africa. 2nd International Conference: Climate, sustainability and development in Semiarid Regions August 16 - 20, 2010, Fortaleza - Ceará, Brazil.

2. Bryan E, Deressa TT and Ringler C. 2009. Adaptation to climate change in
Ethiopia and South Africa, Options and constraints. Environmental Science and Policy, 12(4): 413-426.

3. DEA 2014. Climate change perceptions and local adaptation strategies of hazard prone rural household of Bangladesh, climate risk management, volume 17, Bangladesh.

4. Morton 2017. Assessing farmers' perception about climate change, climate risk management, 17, 123-138.

5. Ravishankar. 2013. A study on constraints faced by Farmers in adapting to climate change, Hum Ecol, 44:23-28, NDRI

6. Sarkar S and Padaria RN. 2010. Farmers' awareness and risk perception about climate change in Coastal Ecosystem of West Bengal, Indian Research Journal of Extension Education 10 (2): 32-38.

7. Shalander K, Raj BMK and B Venkateswarlu. 2011. Sensitivity of yields of major rainfed crops to climate in India. Indian J. Agric. Econ., 66(3): 55-58.

\section{How to cite this article:}

Debasmita Nayak, Mita Meher, Sushree Purabi Panigrahi and Sangramsingh, S.P. 2019. Impact of Climate CHANGE on Agriculture and Allied Activities in Jagatsinghpur District of Odisha. Int.J.Curr.Microbiol.App.Sci. 8(09): 921-926. doi: https://doi.org/10.20546/ijcmas.2019.809.108 